RESEARCH PAPER

\title{
ISOLATION OF PENTACYCLIC TRITERPENES FROM SIMIRA SAMPAIOANA (STANDL.) STEYERM (RUBIACEAE)
} as Possible AnticanCER Agents

\author{
Cristina Borges Viana, Lidilhone Hamerski Carbonezi, Roberto Carlos Campos Martins* \\ Institute of Natural Product Research, Federal University of Rio de Janeiro, Rio de Janeiro, RJ, Brazil \\ *E-mail: roberto@nppn.ufrj.br \\ Tel.: +55 2139386512 .
}

Received: Apr 24, 2017 / Revised: Apr 30, 2017 / Accepted: Apr 30, 2017

\begin{abstract}
Botanical genus Simira belongs to Rubiaceae and its more than 40 species are predominantly neotropical and woody. Simira sampaioana (Standl.) Steyerm is popularly known as Arariba or Maiate in the brazillian states of Minas Gerais, Goiás, São Paulo and Rio de Janeiro, and its wood is widely used in reforestation. Phytochemical study of alcoholic extract from the leaves of this plant, aiming the search of bioactive natural products and its chemical constitution as part of a future metabolomic study, led to the isolation and identification of four acid triterpenes. ID and 2D NMR andn HRESIM-MS confirmed the identity of these terpenoid substances as pomolic acid, sumaresinolic acid and the position isomers hederagenin and 23-hydroxy-ursolic acid. Pomolic acid, hederagenin and 23-hidroxyursolic acid have significant biological activities, especially as antitumoral and anti-inflammatory agents. This is the first report of a phytochemical study of this Rubiaceae species and these isolated substances have never been found in the genus simira so far.
\end{abstract}

Key words: Simira sampaioana, Rubiaceae, triterpenes.

\section{INTRODUCTION}

Plants produce a wide variety of secondary metabolites, both nitrogen-containing and nitrogen-free, that play an important role in their biological properties (Jain et al 2011; Jenny et al 2012; Deb et al 2013; Sadanand and Palanivelu, 2015; Gajendiran et al 2016; Shrestha et al 2016).

Pentacyclic triterpenes are widely distributed throughout the plant kingdom, in a free form, either as aglycones or triterpenoid saponins, having both a wide range of important biological activities.

Development of highly efficient and low-toxicity anti-cancer drugs is one of the most urgent issues in medical field. Triterpene acid compounds have the desirable characteristics of being natural, present low toxicity and a high efficiency, which allows them to be considered as promising antitumor drugs (Zhang et al 2014).

Genus Simira belongs to Rubiaceae and it is predominantly neotropical, woody, comprising more than 40 species. Out of these, 19 occur in Brazillian Atlantic forest, 8 in the Southeast of Brazil (Silva Neto and Callado, 2008). Simira sampaioana (Standl.) Steyerm is popularly known as Arariba or Maiate, and its wood is widely used in reforestation. In Brazil, this plant can be found in the states of Minas Gerais, Goiás, São Paulo and Rio de Janeiro, being one of the 5 species of Simira which occur in this state (Silva Neto and Callado, 2008).

As literature, so far, has no records of phytochemical studies of this plant, and aiming to search possible biologically active metabolites, Simira sampaioana was chosen as the main target of this research. Thus, this 
present study reports the isolation and identification of the pentacyclic triterpenes with anticancer activity from the leaves of Simira sampaioana.

\section{EXPERIMENTAL}

\section{Materials and Methods}

The plant material collected in the National Park of Itatiaia- Rio de Janeiro (Brazil) in October, 2002 and identified by Dr. José Sebastião da Silva Neto (UFRJ). A voucher specimen is deposited in the herbarium of the Institute of Biology/UFRJ under the number RFA-31.796.

\section{Procedure for extraction}

Part of the dried and crushed leaves (100 g) of $S$. sampaioana were extracted separately with ethyl acetate and methanol by exhaustive percolation. Filtration and further evaporation of the solvents under vacuum, yielded methanolic $(13.2 \mathrm{~g})$ and ethyl acetate (9.2 g) extracts. Methanolic extract was fractionated through a silica-gel column chromatography using dichloromethane, ethyl acetate and acetone as eluents successively, and it yielded the dichloromethane (PDCM - $345 \mathrm{mg}$ ), acetone (PA: $863.8 \mathrm{mg}$ ) and ethyl acetate (Pac: $9.637 \mathrm{~g}$ ) fractions. PAc fraction was refractionated through a flash silica-gel column using a gradient of hexane : dichloromethane : ethyl acetate : methanol (100\% hexane to $100 \%$ methanol). 14 fractions were obtained and the fraction PAc7 (15.1 mg) showed a high purity level when analysed by TLC, and so it was chosen to be analysed by MS and $1 \mathrm{D}$ and $2 \mathrm{D}{ }^{1} \mathrm{H} /{ }^{13} \mathrm{C}$ NMR.

Achieved data were compared to the literature and led to the identification of this substance as the triterpene pomolic acid (1). The PAc9 fraction (226.1 $\mathrm{mg})$ was chromatographed on silica gel column and eluted with dichloromethane : acetate : methanol (100\% dichloromethane to $100 \%$ methanol). Fractions 31-63 were reunited after showing similarity in analytical TLC and submitted to a new column chromatography using as eluent hexane : dichloromethane : methanol $(1: 1: 0-1$ : 1 : 0.3). From this experiment, fraction 12 (7.6 $\mathrm{mg}$ ) showed the presence of a single spot in TLC analysis. 1D and 2D NMR and MS data, compared to the literature, led to its identification as the triterpene sumaresinolic acid (2).

Ethyl acetate extract $(3,625$-EAc) was subjected to a silica-gel chromatography column with hexane: dichloro methane:acetate:methanol (100\% hexane to $100 \%$ methanol), and 9 fractions were obtained. EAc6 fraction (724.8 $\mathrm{mg}$ ) was re-chromatographed through a silicagel column chromatography using hexane : dichloromethane $\quad(100 \%$ hexane - $90 \%$ dichloromethane) and hexane : dichloromethane : ethyl acetate (20:20:1-20:20:7) as eluents. From this chromatography, the EAc6 fraction (97-104) (141.6 mg) showed to be apparently pure and it was submitted to a new silica-gel column chromatography eluted with hexane/ dichloromethane/methanol (1:1:0-1:1:0.8). It yielded EAc6 (97-104) 44-45 fraction (12.4 mg) whose NMR data and comparison with literature revealed its structure as mixture of two triterpenes, which are isomers, hederagenin (3) and 23-hydroxy-ursolic acid (4).

\section{RESULTS AND DISCUSSION}

After accurate analysis of all the data obtained, it is correct to state that isolated substance $\mathbf{1}$ is the pomolic acid (Figure 1), also known as randalic acid, $19 \alpha$-hydroxyfuranosolic acid or $3 \beta-19 \alpha-$ dihydroxy-urs-12-en-28-oic acid.

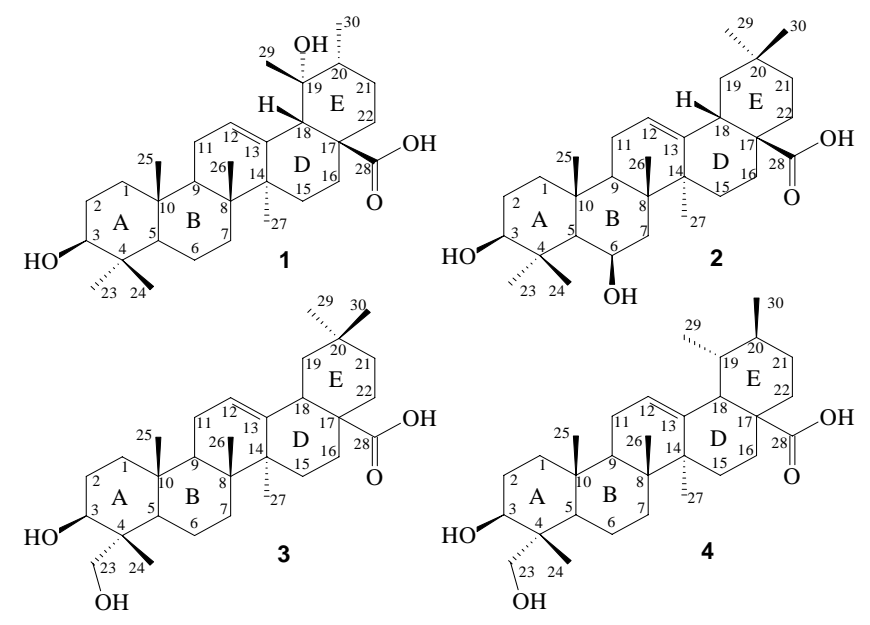

Fig. 1. Acid triterpenes identified from the leaf extracts of S. sampaioana 
This metabolite was isolated from fresh fruits of Ilex crenata as both an aglycon and in glycosylated forms as a saponin (Kakuno et al 1992). Its antitumoral activity has been studied in the literature, showing 70 to $90 \%$ of efficiency against eight different types of cancer cells, even those with multiple drug resistance (Fernandes et al 2005). Testa and co-workers evaluated the anti-inflammatory activity of extracts of Guettarda pohliana roots and leaves containing ursolic, oleanolic, pomolic, rotundic and quinovic acids in 2012 and found out that administration of the topical $2.5 \mathrm{mg}$ dose of the crude extract and leaf fractions inhibited the edema in $65 \%$. In assays for the evaluation of antiplatelet activity, pomolic acid, isolated from Licania pittieri, presented a potent competitive antagonist of the P2Y12 receptor, in vitro, thus exhibiting antiplatelet activity (Alvarado-Castillo et al 2012). For this acid triterpene, also isolated from Licania pittieri, a previous research showed its potent vasorelaxant activity (Estrada et al 2011). Within Rubiaceae, pomolic acid has already been found in the genera Randia, Mussaenda, Guettarda and Alibertia, but there are no reports of the isolation of this substance in the genus Simira.

Another acid triterpene isolated from $S$. sampaioana was sumaresinolic acid (2), also known as $3 \beta$-6 $\beta$-dihydroxy-olean-12-em-28-oic acid. Although this substance has never been biologically tested in its isolated form, extracts from parts of several plants, containing this terpenoid compound, have shown significant activities such as the resin of Chinese Styrax tonkinensis with expectorant activity (Wang et al 2006) and seeds of Pterospermum heterophyllum, used in the treatment of rheumatoid arthritis in China (Lia et al 2009). This is also the first report of the isolation of

\section{REFERENCES}

Alvarado-Castillo C, Estrada O, Carvajal E. Pomolic acid, triterpenoid isolated from Licania pittieri, as competitive antagonista of ADP-induced aggregation of human platelets. Phytomedicine 2012;19(6):484-7. [DOI: 10.101 6/j.phymed.2011.12.011]

Chwalek M, Lalun N, Bobichon H, Plé K, VoutquenneNazabadioko L. Structure activity relationships of some hederagenin diglycosides: Haemolysis, cytotoxicity and apoptosis induction. Biochim. Biophys. Acta 2006; 1760(9):1418-27. [DOI: 10.1016/j.bbagen.2006.05.004]

Deb L, Bhattacharjee C, Shetty SR, Dutta A. Evaluation of anti-diabetic potential of the Syzygium cuminii (linn) skeels by reverse pharmacological approaches. Bull. Pharm. Res. 2013;3(3):135-45. sumaresinolic acid from the genus Simira, although it has already been previously isolated from other Rubiaceae.

Hederagenin (3) and 23-hidroxyursolic acid (4) were identified as a mixture after analysis of the data acquired from the 1D and 2D NMR experiments and also ESI-MS. These acid triterpenes have also been demonstrated to possess prominent biological activities. Hederagenin in its glycosilated form, isolated from Sapindus saponaria showed antifungal activity (Tsuzuki et al 2007) and also antidepressant, hemolytic, cytotoxic and antitumoral activities have been already described for this terpene (Zhou et al 2010, Chwalek et al 2006, Park et al 2001). 23hidroxyursolic acid is a triterpene with significant antinociceptive and anti-inflamatory activities. It is also a substance with proven ?glucosidase inhibition, having potential to be used in the treatment of diabetes (Tapondjou et al 2003; Wenli et al 2009).

This is also the first report for the occurrence both triterpenes in the genus Simira, although they have been previously been described in other species of Rubiaceae.

\section{CONCLUSION}

Four acid triterpenes were isolated for the first time in the genus Simira and also in the species Simira sampaioana, as is it is the first report of a phytochemical study of this plant. Three of them possess well-documented biological activities, which makes them targets for further studies towards their use as potential drugs. Results also allow to state $S$. sampaioana as a source of these metabolites.

\section{ACKNOWLEDGEMENTS}

This work was supported by CAPES and CNPq.

Estrada O, González-Guzmán J M, Salazar-Bookaman M, Fernández AZ, Cardozo A, Alvarado-Castillo C. Pomolic acid of Licania pittieri elicits endothelium-dependent relaxation in rat aortic rings. Phytomedicine 2011;18: 464-9. [DOI: 10.1016/j.phymed.2010.10.008]

Fernandes J, Weinlichb R, Castilho RO, Kaplan MAC, Amarante-Mendes GP, Gattassa CR. Pomolic acid triggers mitochondria-dependent apoptotic cell death in leukemia cell line. Cancer Lett. 2005;219;49-55. [DOI: 10.1016/j.c anlet.2004.09.001]

Gajendiran A, Thangaraman V, Thangamani S, Ravi D, Abraham J. Antimicrobial, antioxidant and anticancer screening of Ocimum basilicum seeds. Bull. Pharm. Res. 2016;6(3):114-9. [DOI: 10.21276/bpr.2016.6.3.5] 
Jain RA, Agarwal RC, Pandey A, Jain R. Evaluation of Argemone mexicana fruits extract using micronucleus assay in mouse bone marrow cells. Bull. Pharm. Res. 2011;1(2):22-4.

Jenny A, Saha D, Paul S, Dutta M, Uddin MZ, Nath AK. Antibacterial activity of the aerial part of extract of Elephantopus scaber Linn. Bull. Pharm. Res. 2012;2(1):3841.

Kakuno T, Yoshikawa K, Arihara S. Triterpenoid saponins from Ilex crenata fruit. Phytochemistry 1992;31(10): 3553-7. [DOI: 10.1016/0031-9422(92)83726-F]

Lia S, Shi Y, Shang X, Cui B, Yuan Y, Chen X, Yanga Y, Shia J. Triterpenoids from the roots of Pterospermum heterophyllum Hance. J. Asian Nat. Prod. Res. 2009;11(7): 652-7. [DOI: 10.1080/10286020902964248]

Park H, Kwon S, Lee J, Lee K, Miyamoto K, Lee K. Kalopanaxsaponin A is a basic saponin structure for the anti-tumor activity of hederagenin monodesmosides. Planta Med. 2001;67(2):118-21. [DOI: 10.1055/s-2001-11 516]

Sadanand VK, Palanivelu M. Investigation of the pharmacological activity of ethanolic extract of Abrus precatorius seeds. Bull. Pharm. Res. 2015;5(1):28-30.

Shrestha DK, Sapkota H, Baidya P, Basnet S. Antioxidant and antibacterial activities of Allium sativum and Allium cepa. Bull. Pharm. Res. 2016;6(2):50-5. [DOI: 10.21276/bpr.20 16.6.2.3]

Silva Neto SJ, Callado CH. A New Species of Simira (Rubiaceae, Simireae) from Rio de Janeiro, Brazil. Novon 2008;18(3):387-9. [DOI: 10.3417/2006056]

Tapondjou LA, Sondengam BL, Choi J, Kyungtae L, Hyung-Ju J, Park H. In Vivo anti-nociceptive and anti-inflammatory effect of the two triterpenes, ursolic acid and 23hydroxyursolic acid, from Cussonia bancoensis. Arch. Pharm. Res. 2003;26(2):143-6. [DOI: 10.1007/BF029766 60]

Testa G, Oliveira PRN, Silva CC, Schuquel ITA, Santin SMO, Kato L, Oliveira CMA, Arruda LLM, Bersani-Amado CA. Constituintes químicos das folhas e avaliação da atividade anti-inflamatória de extratos das raízes e folhas de Guettarda pohliana MÜLL. ARG. (Rubiaceae). Quím. Nova. 2012;35(3):527-9. [DOI: 10.1590/S0100-404220120003 00016]

Tsuzuki JK, Svidzinski TIE, Shinobu CS, Silva LFA, Rodrigues-Filho E, Cortez DAG, Ferreira ICP. Antifungal activity of the extracts and saponins from Sapindus saponaria L. An. Acad. Bras. Ciênc. 2007;79(4):577-83. [DOI: 10.1590/S0001-37652007000400002]

Wang F, Hua H, Pei Y, Chen D, Jing Y. Triterpenoids from the resin of Styrax tonkinensis and their antiproliferative and differentiation effects in human leukemia HL-60 cells. J. Nat. Prod. 2006; 69(5): 807-10. [DOI: 10.1021/np050 371z]

Wenli H, Yanfang L, Qiang Z, Xin W, Aihua P, Lijuan C, Yuquan W. Triterpene acids isolated from Lagerstroemia speciosa leaves as $\alpha$-glucosidase inhibitors. Phytother. Res. 2009;23(5):614-8. [DOI: 10.1002/ptr.2661]

Zhang W, Men X, Lei P. Review on anti-tumor effect of triterpene acid compounds. J. Can. Res. Ther. 2014;10(1): 14-9. [DOI: 10.4103/0973-1482.139746]

Zhou D, Jin H, Lin H, Yang X, Cheng Y, Deng F, Xu J. Antidepressant effect of the extracts from Fructus Akebiae. Pharmacol. Biochem. Behav. 2010; 94(3): 488-95. [DOI: 10.1016/j.pbb.2009.11.003] 